\title{
18
}

\section{Intimate Partner Homicide}

\section{Daniel G. Saunders and Angela Browne}

\section{Introduction}

\begin{abstract}
Despite her pregnancy, LaQuana decided that she must leave her boyfriend, Blakely. He had been physically assaulting her for over a year, and she believed she had to leave him for the safety of herself and her child. One night, Blakely found her at her family's home with her mother and brother. He insisted that she come back to him. When he tried to force her to go with him, LaQuana threatened to call the police. Blakely then announced his intention to kill everyone in the house. He shot and killed LaQuana, and also shot and wounded her mother as she tried to shield LaQuana. In court, Blakely claimed that he accidentally shot LaQuana while struggling with her brother, who had reached for the gun. (adapted from Michigan Domestic Homicides, 1995-1996)
\end{abstract}

Could anything have prevented this tragedy? Professionals and the public alike ask such questions when they hear about homicides in families. Attempts to understand homicides between husbands and wives and boyfriends and girlfriends raise a number of additional questions. Are rates of homicide between intimate partners increasing or decreasing? How do partner homicides differ from other kinds of homicide? What are the motives? Are there risk factors we can identify? In hindsight, it often seems that there were clear signs that a tragedy might occur, but how useful are these signs for predicting future tragedies?

Daniel G. Saunders - School of Social Work, University of Michigan, Ann Arbor, Michigan 48109. Angela Browne - Harvard Injury Control Center, Harvard School of Public Health, Boston, Massachusetts 02115.

Case Studies in Family Violence, Second Edition, edited by Ammerman and Hersen. Kluwer Academic / Plenum Publishers, New York, 2000. 
In this chapter, we describe the extent of and trends in homicide between intimate partners and synthesize the empirical evidence available on motives and risk factors. We then present two case studies that illustrate some common dynamics of partner homicide and discuss society's responses to the problem. A major emphasis will be on differences in rates, trends over time, and motives for homicides by women and men perpetrators. We use the terms partner or intimate partner homicide throughout to mean homicides occurring between current or former dating, cohabiting, commonlaw, and married heterosexual couples. An enhanced understanding of the dynamics of homicide between intimate partners may prove useful for preventing it in future generations. Prevention may also occur in current relationships by identifying persons and situations at greatest risk. Although the prediction of rare events like homicide is always difficult, many in the mental health and criminal justice fields are now asked to attempt such predictions, and the seriousness of the problem alone means that we should take advantage of our growing - if imprecise-knowledge (Monahan, 1996).

Until recently, homicide between partners was relatively ignored as an area of study. Most research focused on stranger and acquaintance killings, with only brief statistical descriptions of other categories. Clinical case studies existed on homicide between partners, but these created the impression that such homicides were rare and idiosyncratic events. Existing empirical studies often failed to identify trends over time or to explore differences in partner homicides by gender of the perpetrators and type of intimate relationships (e.g., partner versus ex-partner; married versus unmarried; Browne \& Williams, 1993). Unfortunately, without these analyses, important differences in intimate partner homicide remained hidden.

Homicide in general is a serious problem in the United States. The rate of homicide just within families in this country is higher than the total homicide rates in most other Western industrialized nations (Browne, Williams, \& Dutton, 1999). These unusually high levels of lethal aggression are not new; a multicountry comparison of homicide rates for all victims over 14 years of age between the years of 1950 and 1980 found that U.S. rates were nearly three times as high as the next highest country (Gartner, 1990). Homicides between intimate partners are the most common type of homicide occurring within families (e.g., Dawson \& Langan, 1994; Kellerman \& Mercy, 1992). ${ }^{1}$ From 1976 through 1996, approximately 52,000 men and women were killed by an intimate partner in the United States (Green-

${ }^{1}$ Compared with nonlethal forms of violence between intimate partners, however, partner homicide is still a relatively rare event. Over 12 million husbands and wives admit to using aggression every year (Straus \& Gelles, 1990), making it over 5,400 times as likely as partner homicide. This does not mean that 1 out of 5,400 intimate violence cases ends in homicide, because homicide may not always be preceded by other marital violence (cf. Campbell, 1981; Scott, 1974). 
field, Rand, Craven, Klaus, Perkins, Ringel, Warchol, Maston, \& Fox, 1998). These homicides represented $14 \%$ of all homicides in 1976 (about 3,000 per year) and 9\% of all homicides in 1996 (about 2,000 per year).

National statistics on homicide are drawn from the Supplementary Homicide Reports (SHR), filed by the police at the time a homicide is investigated and collected by the FBI as a part of its Uniform Crime Reporting program. These reports include only brief descriptions of the context of the incident (e.g., domestic argument, drug-related), the means used to kill, and the relationship between victim(s) and perpetrator(s) if known to the police. Almost all police jurisdictions participate in filing Supplementary Homicide Reports, although data are based on those suspected to be perpetrators at the time of the investigation, and approximately $31 \%$ of homicides may still be under investigation when an SHR is filed; the identity of those offenders is often listed as "unknown" (Kellerman \& Mercy, 1992). Despite these problems with the SHR, there appears to be a significant decline in intimate homicides over the past 20 years in this country. In one analysis for 1976 through 1996, the rate for homicides of marital partners fell $52 \%$ and the rate for total partner homicides fell $36 \%$ (Greenfield et al., 1998). Another SHR analysis of trends in partner homicide for the years of 1980 through 1995 that adjusted for missing data in the SHR also noted a decline (Browne, Williams \& Dutton, 1999). However, changes in homicide rates over time varied sharply by gender of the perpetrator and type of intimate relationship. Analyses on the individual level by gender, relationship status, race and other factors are revealing. Social structural and resource factors on the state level related to changing rates also suggest strategies for prevention and intervention.

\section{Risk Factors}

\section{Gender Differences}

Women are especially at risk of partner homicide. Although men are at higher risk of being killed by an acquaintance or stranger than an intimate, women are more likely to be killed by a current or former spouse or boyfriend than by any other type of assailant (Browne et al., 1999; Greenfield et al., 1998; Langan \& Dawson, 1995; Plass \& Straus, 1987). Before the mid-1980s, the number of women victims of intimate homicide was not much higher than that of men victims. However, by the 1990s, about three women were killed for every man. Of all partner homicides in recent years, about $70 \%$ of the victims are women killed by male partners and $30 \%$ are men killed by female partners. The major reason for this increasing gender gap is a substantial decline in the rates of husbands and ex-husbands being killed by wives. A decrease in homicides of wives and 
ex-wives also has occurred, but the decline is not as dramatic (Browne et al., 1998; Dugan, Nagin, \& Rosenfeld, in press; Greenfield et al., 1998). The rate of girlfriends and ex-girlfriends killed by their male partners remained about the same over the past 20 years (Greenfield et al., 1998), although it increased during portions of the time period (Bixenstine, 1996; Browne et al., 1998), with a slight overall increase in the killing of white girlfriends (Greenfield et al., 1998). Browne and Williams (1993) speculate that the increased homicides of unmarried women in the early 1980s may be from the emphasis placed on married women by intervention programs and legal protections. For example, in some states, legal provisions and other services for dating couples lagged behind those for married couples. Alternatively, the informal, ambiguous nature of dating relationships may arouse more fear of abandonment in men, a risk factor described later.

\section{Racial Differences}

Black and Native American populations are at particularly high risk for partner homicide, whereas Latino partner homicide rates are below those of black and non-Hispanic whites (for a review see Hampton, Carrillo, \& Kim, 1998). Between 1976 and 1997, rates for partner homicides among blacks averaged 5 to 10 times higher than for whites (Greenfield et al., 1998; see also Block \& Christakos, 1995; Goetting, 1995; Mercy \& Saltzman, 1989; Plass \& Straus, 1987). This finding is consistent with high rates of nonfamily homicide (e.g., O'Carroll \& Mercy, 1986) and nonlethal family violence among American blacks (Cazenave \& Straus, 1979). As in the overall statistics, over the past two decades there has been a steady decrease in partner homicide among blacks, much of it due to a decline in homicides against black partners by black women (Greenfield et al., 1998; Mercy \& Saltzman, 1989; Rosenfeld, 1997).

A number of explanations exist for the relatively high rate of lethal and nonlethal family violence by blacks. An earlier theory that blacks constitute a subculture that accepts violence has been largely disproven by studies that include other explanatory variables. As Hampton (1987) pointed out, black homicide rates are much more highly associated with social structural factors-especially poverty and level of employmentthan with ethnicity itself. Centerwall (1995) found that the higher rates of black partner homicide in one city disappeared after controlling for household crowding, a proxy for low socioeconomic status (SES). Similar findings exist for nonlethal partner violence, where low income and occupational status explains higher rates for blacks (Cazenave \& Straus, 1979). Black women may become scapegoats for the frustration felt by black men in a society that promises opportunities for success but discriminates racially (Harvey, 1986; White, 1985). Ecological models that include the 
stress of urban living and high-risk environments in addition to poverty also have been proposed (Hampton, 1987). A recent review indicated that social instability and change within a community also are stronger risk markers than poverty (Hampton, Carrillo, \& Kim, 1998).

Social response to nonlethal violence may also be a factor. Black women may be reluctant to rely as much on the criminal justice system for protection and are especially vulnerable to violence because of racism and poverty (Harvey, 1986; Hawkins, 1987). Hawkins linked the devaluation of black life in America and the reluctance of a dominant society to aid victims to high mortality rates in the black community. A lack of medical help, for example, can make the difference between serious injury and death.

\section{Prior Assaults}

Because Supplementary Homicide Reports do not contain information about the prior interactions of specific couples, no national estimates are available on the number of partner homicides that involve a history of physical assault or threat prior to the lethal incident (Browne, 1997). However, more detailed studies of homicides with smaller samples indicate that a significant proportion of partner homicides by women occur in response to an assault, a history of assault, or threats (e.g., Browne, 1987; Chimbos, 1978; Daly \& Wilson, 1988; Daniel \& Harris, 1982; Goetting, 1987; Kellerman, Rivara, Rushforth, \& Banton, 1993; Rosenfeld, 1997; Totman, 1978; Wilbanks, 1983). In an examination of prosecution cases, women were four times more likely than men to have faced a weapon or been assaulted at or around the time of the murder (Langan \& Dawson, 1995). Both clinical and research studies document a history of physical assaults by men who eventually kill their female intimates (e.g., Campbell, 1992; Crawford \& Gartner, 1992; Dutton \& Kerry, 1996; Wolfgang, 1958). The escalation or a high frequency of violence may be additional risk markers for partner homicide (Browne, 1987; Kellerman et al., 1993; Straus, 1996). Stalking and harassment by men also may be precursors of homicides by men (e.g., Browne, 1986; Meloy, 1998) or by women in response to threatening behaviors by current or former male partners (e.g., Campbell, 1992; Wilson \& Daly, 1995).

\section{Motives}

Empirical findings strongly suggest a self-defense motive for many women perpetrators of partner homicide. As far back as Wolfgang's (1958) classic study of criminal homicide in Philadelphia, the importance of selfdefense in partner homicides by women was noted. In analyzing police 
and court records, Wolfgang found that at least $60 \%$ of husbands killed by their wives had "precipitated" their own deaths; that is, they were the first to use physical force, strike blows, or threaten with a weapon, compared to only $9 \%$ of wife victims (Wolfgang, 1958). These figures were based on "provocation recognized by the courts" and do not necessarily reflect the number of wives who had actually experienced physical abuse or threat from their partners.

Studies of abused women who kill indicate that they often feel hopelessly trapped in a desperate situation from which they see no avenue of safe escape (e.g., Browne, 1987; Hamilton \& Sutterfield, 1997; Totman, 1978). Compared with other battered women, battered women who kill are more likely to be unemployed (Goetting, 1995; Roberts, 1996), to have less social support (Dutton, Hohnecker, Halle, \& Burghardt, 1994), to suffer more frequent assaults and receive more severe injuries (Browne, 1987; Gillespie, 1989), to be raped by their partners (Browne, 1987), to use less violence against their partners (O'Keefe, 1997), to be threatened with death by their partners, and to believe their lives are in danger (Browne, 1987; O'Keefe, 1997). The homicide occurs as part of an attempt to stop their partner from harming them or a child any further, to prevent an attack they believe to be imminent and life-threatening, or during a violent assault (Browne, 1986, 1987; Dugan, Nagin, \& Rosenfeld, in press; Grant, 1995; Jurik \& Winn, 1990; Maguigan, 1991). In one study of intimate homicide, women reported a much higher level of fear than men who killed women partners (Stout \& Brown, 1995). Mann (1992) also found that women often reported a self-defense motive ( $32 \%$ men to $57 \%$ women in two cities), but she interpreted these reports as "excuses" by the women (Mann, 1988). However, based on evidence of prior assaults, threats, and physical injuries, judges and juries seem generally to believe that such homicides are in self-defense or that there were strong mitigating circumstances. Women are more likely than men to be screened out of prosecution because of selfdefense or, if tried, to have lower conviction rates and shorter prison sentences when convicted (Langan \& Dawson, 1995).

In contrast to the predominance of a self-defense motive for women, empirical and clinical studies indicate that men's motives appear to revolve more around jealousy or the imminent or actual termination of a relationship (Barnard, Vera, Vera, \& Newman, 1982; Block \& Christakos, 1995; Cazenave \& Zahn, 1992; Goetting, 1995; Stout, 1993; Wilson et al., 1995). Self-defense is estimated to be 7 to 10 times less frequent for husbands than for wives (Campbell, 1981; Wolfgang, 1958). As illustrated by the opening vignette, there is growing evidence that separation or the threat of separation is a significant precipitant of partner homicides by men (Campbell, 1981; Wilson \& Daly, 1993; Wilson, Johnson \& Daly, 1995). 
Wilson and colleagues contend that this is due to the perception among some men that they are entitled to control the lives of their wives or girlfriends. Indeed, early psychiatric evaluations of men who killed women partners (Barnard et al.,1982) indicated that the precipitating event in male-perpetrated partner homicide was usually some type of perceived rejection on the part of the woman. Separation or threat of separation was especially threatening, being interpreted by the men to represent "intolerable desertion, rejection, and abandonment" (p. 278). In killing their wives, men believed they were responding to an offense against them: the woman leaving. Other studies found both estrangement and jealousy as reasons for the killing of wives (e.g., Campbell, 1981; Crawford \& Gartner, 1992; Goetting, 1995). Campbell (1981) placed these men's jealousy within the context of a patriarchal culture. She reviewed studies linking "machismo" culture with greater violence toward women and contended that, "Because women are considered the possession of men in patriarchy, real or imagined sexual infidelity is the gravest threat to male dominance" (p. 78). Estrangement homicides by men were also characterized in one study (Ontario, 1974-94) by offenders who were unemployed (75\% vs. $59 \%)$, had a criminal record (71\% vs. $55 \%)$, and used a gun ( $41 \%$ vs. $30 \%)$ (Dawson \& Gartner, 1998).

Male-perpetrated partner homicides often occur soon after separation. Recent data suggest that about half of estrangement homicides occur within 2 months of separation, and almost all occur within a year. For example, Stout (1993) found that over half $(60 \%)$ of estrangement killings occurred within 1 month; $90 \%$ were within 1 year; Wallace (1986) found nearly half $(47 \%)$ within 2 months and $76 \%$ within a year; Wilson and Daly (1993) found half within 2 months and $87 \%$ within a year. These studies indicate that the time period immediately following leaving an abusive mate may be an especially dangerous time for a woman. However, homicides by male partners also may occur months or even years after the couple are separated or divorced.

\section{Types of Abusers}

Although there are some common patterns, men who perpetrate partner homicides vary on ethnic, socioeconomic, and behavioral dimensions. Even in studies of men who perpetrate nonlethal violence toward women intimates, there are many differences between perpetrators. Some studies of nonlethal cases show distinctions among men who batter that seem to relate types of abuse they perpetrate with different types of childhood experiences and with resulting attachment and personality disorders (Holtzworth-Munroe \& Stuart, 1994). For example, severe physi- 
cal abuse in childhood is empirically linked with antisocial traits, generalized aggression, alcoholism, and severe violence against an intimate partner in adulthood (Saunders, 1995). However, severe violence by a man against his partner may not be the best predictor of partner homicide. This antisocial type may be the most intimidating and controlling, but his "distancing" attachment style may help him let go of intimate relationships more easily than other types of personalities. The borderline/dysphoric type, on the other hand, is an individual who experienced emotional rejection in childhood and developed an "anxious" attachment style and the greatest fear of abandonment (see Dutton, 1998). He is more likely to have a history of suicide attempts and help seeking and, while he may be quite psychologically abusive, his physical abuse in the relationship often is not severe (Saunders, 1992). Although much empirical work remains to be done, it is the borderline/dysphoric batterer who appears most at risk to kill his partner. Stout's (1993) study of men incarcerated for the murder of their women partners gave support to this link; men who killed their partners reported more emotional abuse (witnessing violence, alcoholic parents) than physical abuse in their childhoods. Humphrey and Palmer (1982) found more childhood losses among men who killed their partners than among extrafamilial killers or nonviolent men.

\section{Suicidality}

Homicide-suicide occurs in only a small proportion of homicide cases. Men are more likely to kill themselves following the commission of a partner homicide than are women (e.g., Block \& Christakos, 1995; Cooper \& Eaves, 1996). Homicide-suicide is much more likely in cases of partner femicide than non-partner femicide (Moracco, Runyan, \& Butts, 1998). When considering only partner homicides by men, homicide-suicides comprise a substantial minority of cases: $15 \%$ in Chicago (Block \& Christakos, 1995); $27 \%$ in North Carolina (using medical records and law enforcement officer interviews (Morton, Runyan, Moracco, \& Butts, 1998); $24 \%$ in Canada (Daly \& Wilson, 1988); $32 \%$ (plus $12 \%$ serious suicide attempt) in British Columbia (Cooper \& Eaves, 1996); 19\% in Philadelphia (Wolfgang, 1967); and 26\% in one Florida county (Wilbanks, 1983) [ave. = $24 \%$ ]. As found with other intimate homicides by men, the perpetrator typically develops suspicions about his partner's infidelity, real or imagined, and the triggering event is often her withdrawal or estrangement (e.g., Cooper \& Eaves, 1996; Danson \& Soothill, 1996; Marzuk, Tardiff, \& Hirsch, 1992). Only a small percentage of cases seem to involve "mercy killings," in which the woman is in declining health and there is little prior conflict (Morton, Runyan, Moracco, \& Butts, 1998). In a detailed analysis of 
the impact of loss and jealousy on male-perpetrated partner homicide, Rasche (1988) found that men who killed because their relationship ended were more likely to commit suicide after the homicide, whereas men who killed out of jealousy were more likely only to kill their partners.

\section{Alcohol and Other Drugs}

Alcohol and other drugs have long been associated with violent crime, and intimate homicide is no exception. Associations have been found in national FBI data (e.g., Kellerman et al., 1993), city data (e.g., Goetting, 1995), pretrial studies (e.g., Browne, 1987), and surveys of prosecutors' records (e.g., Langan \& Dawson, 1995). Here again, there are gender differences. For example, in a survey of prosecutors' records, $66 \%$ of husband perpetrators and $37 \%$ of wife perpetrators had been using alcohol at the time of the homicide, and $22 \%$ of the husband perpetratorsbut only $3 \%$ of the wife perpetrators-had used illegal drugs (Langan \& Dawson, 1995). Similar findings were found in one state's review of medical examiner data and interviews with police investigators (Smith, Moracco, \& Butts, 1998).

However, a high correlation with alcohol or other drug use does not mean that substance abuse directly causes lethal aggression (Gondolf, 1995). Although studies of nonlethal partner violence find that men who are violent toward women partners are more likely to abuse alcohol or other drugs than are nonabusive men (Bennett, 1995), alcohol does not seem to have a disinhibitory effect on a physiological level; rather, it may have an association with violence because of other factors such as macho attitudes, constricted information-processing ability, or a socially supported excuse or "time-out" from sanctions. Abusive men with alcohol or drug problems do attack their wives more frequently, are more apt to inflict serious physical injuries on their partners, and are more likely to assault their partners sexually than abusers without a history of substance abuse (e.g., Frieze \& Browne, 1989). Thus substance abuse may increase the risk that a seriously injurious or fatal incident will occur.

\section{Firearms}

While the majority of those murdered by an intimate are killed by a firearm, the 20-year decline in intimate homicides is paralleled by a decline in such homicides committed with firearms-from $71 \%$ in 1976 to $61 \%$ in 1996 (Greenfield et al., 1998). Firearm assaults in the family are 12 times more likely to result in death than non-firearm assaults (Saltzman, 1992). Here there are either no gender differences or greater use of firearms by 
women in the family (e.g., Goetting, 1995; Smith, Moracco, \& Butts, 1998). Studies suggest that women may have more need of firearms to defend themselves and equalize the strength differences between themselves and their partners (e.g., Chimbos, 1978). Compared to battered women who do not kill, women who kill intimate partners also had greater access to their partners' guns (Roberts, 1996).

\section{Risks to Others}

One cannot assume that only the partner will die in a partner homicide incident. As in LaQuana's murder, family members are sometimes injured or killed as well. Although the rates are low, in about $4 \%$ of cases in which men kill their intimate partners, they also kill others (Block \& Christakos, 1995; Langan \& Dawson, 1995; Wilson, Daly, \& Danielle, 1995). In one small sample study of multiple killings by men, $38 \%$ of the other victims were children, $35 \%$ were people attempting to protect the woman or help her to leave (relatives and friends), and $29 \%$ were perceived sexual rivals (Block \& Christakos, 1995). Conversely, less than $1 \%$ of women who kill partners also kill others as a part of the homicide incident (Block \& Christakos, 1995; Langan \& Dawson, 1995; Wilson, Daly, \& Danielle, 1995).

Because of the differences in motives and behaviors of women and men perpetrators, we will present cases of both female- and male-perpetrated partner homicide. ${ }^{2}$ Risk factors for lethal-and severe nonlethal-partner violence will be highlighted and discussed in a following section. Each case illustrates only some of the possible risk factors, and the reader is cautioned that there is no single type of partner homicide offender.

\section{Case Description 1: A Man Who Killed His Wife}

His friends and relatives described Steve as quiet, gentle, and kind. What mattered most to him were his children, his small business, and his home in the country. He believed that he stood to lose all three of these if his divorce became final. Steve and Sally had been married for 8 years and had two children, ages 6 and 8 , at the time of the incident. They had met at a meeting of Amnesty International. Sally was attracted to Steve by his gentleness and good looks. She could not see his insecurities and his tendency to become dependent on and possessive of women. He worked as a nurse for a school department and she was a special education teacher. The early years of their marriage were stressful but exciting for both of them. Having a child right away and paying off school debts was difficult, but they shared many

2These two case examples had many facts changed in order to hide the identities of the families. 
dreams and worked toward fulfilling them. They built a home in the country and started a business raising goats and selling goat cheese.

The seeds for conflict and for Steve's sense of threat, however, were planted early in the relationship. Sally had more education and made more money than Steve did. Despite his liberal views about new roles for women, the disparity would sometimes aggravate him. He wanted to quit his job to expand their business into a full-time operation. Sally was frightened that their income would be too little and gave him ultimatums about leaving him if he followed through with his plans. He took this as a put-down of his abilities. He also felt she was abandoning him and their dreams.

Another common argument concerned what they each thought was best for the children. The rigidity of Steve's upbringing surfaced at these times. His temper flashed if the children did not eat the "right" food or complete their homework on time. The strictness of his own father could be seen in him. He hated the way his father had treated him; he was frequently made to feel "small" when he did not live up to expectations, and his father had threatened him with a belt. Yet Steve found that he sometimes acted the same way as his father had. Steve's anger doubled whenever he felt that Sally's parents were interfering in their lives, especially with the raising of their children. He never felt accepted by his in-laws because he did not share their religious background.

Occasionally when they argued, Steve would yell at Sally. At first he only raised his voice, but later he would call her names like "stupid" or "bitch" and accuse her of marrying him only for his paycheck or in order to have children. Although Steve's yelling was infrequent, when combined with his much greater size, he intimidated Sally. She became more passive in hopes that his outbursts would stop. Steve learned that a hard stare or storming out of the house was enough for him to get his way. Secretly, Sally began to wonder if she should leave him. She finally developed enough courage to ask for a temporary separation, explaining that it could get their marriage back on track. Steve reacted by begging her not to "throw him out." He held her by the shoulders and shook her. He stopped suddenly and they were both surprised by what he had done. He cried and apologized, saying that he would never touch her again.

A week later, when they were talking alone in the bedroom, Sally again told Steve that she thought it would be best if they separated temporarily. She said that she felt extremely tense near him, that he was sullen all the time, and that he needed help. He again grabbed her by the shoulders and said that he could not leave, his "whole life was here." His fear changed to rage and he began to choke Sally. He pushed her onto the bed shouting, "No! No! No!" The shouting brought the children to the door and he stopped. He left the house quickly and called later to say he was moving out. Sally obtained a restraining order to keep him away. A preliminary divorce hearing established that Steve was allowed to visit the children twice a week.

In his desperation to maintain the relationship, Steve violated the restraining order several times. The judge found him in contempt of court. At 
the time, however, there were no criminal penalties for such a violation. One time, after dropping the children off, Steve yelled to Sally through the window that he had a gun in the car and would kill her and burn down the house if she did not take him back. On another occasion, Sally let him in the house, thinking that would lower the risk of violence. She told him she was going ahead with the divorce. Steve carried her into the bedroom, slapped her, and raped her. Sally went to the local battered women's shelter with the children and stayed for a week. The police took no action because marital rape was not a criminal offense at the time. They also felt that, by letting Steve into the house, Sally was partly responsible for the violence.

About a month before the divorce, while returning the children, Steve pushed his way into the house, beat Sally up, and attempted to rape her. To her, the sexual violence was his statement that she belonged to him and that she would not get away. She felt totally degraded. Sally went to the police and told them she wanted the violence stopped. But because she said she did not want Steve to go to jail, they took no action. They were also tired of her "complaining"; her fear made her seem abrasive and shrill at times.

As the divorce date approached, Steve's violence escalated. On one occasion, he shoved Sally against a wall so hard that she struck her head. Another time he held her arms so tightly that they were bruised for a week. He called her repeatedly at home and at work, either to plead with her or threaten her. Her attorney and co-workers saw her bruises and difficulty walking due to beatings and rapes. They called the police and prosecutor and asked them to take action but were told there was insufficient evidence for arrest. Sally's spirit collapsed and she told a counselor that she felt resigned to more violence, including her own death. She considered relocating to another state but feared she could not get as good a job there; she also did not want to take the children away from their relatives.

Two days before the divorce, Steve brought the children home from a visit and made a last attempt to reconcile. Sally became frightened that he would become violent again and screamed at him to leave. She went toward the phone. Steve got there first and tore it off the wall. Sally ran into the garage and was headed for the car when Steve caught her. He struck her repeatedly on the head with a board that he picked up from the floor. When he saw she was no longer breathing, he went to the neighbors and told them to call the police because someone had killed his wife.

This case illustrates some of the structural components of relationships in which husbands kill their wives, the psychology of the offender and victim, and the responses of social agencies. These dynamics will be discussed later in the chapter. The next case is an example of a woman who killed her husband. This case illustrates the motive of self-defense, noted previously as a common motive among women who kill their partners.

\section{Case Description 2: A Woman Who Killed Her Husband}

Nicole met Gary when she was 27, a few months after an acrimonious divorce from her first husband. She had two small children and was feeling 
overwhelmed and vulnerable. Gary was warm and charming and quickly became involved with the details of her life. They dated for 6 months before living together, and were married by the time they had known one another a year. Gary had a family by a previous marriage; they resided in another state and Nicole knew very little about them.

The first incidents of physical aggression occurred when Nicole and Gary had been dating 5 months. They were at a party at which another man repeatedly asked Nicole to dance, although she refused each time. Gary drank quite a bit that night. (Nicole discovered later that he also used amphetamines daily.) As they left the party, he turned and hit her in the stomach with his fist, asking if she wouldn't rather leave with her "new friend." He apologized by the time they reached home, and the next day he admitted that he was mainly frightened by how much he had come to care about her and how deeply he wanted her to be his. Gary didn't drink heavily during the rest of their courtship, and there were no further assaults. He was the most affectionate man Nicole had ever known, and his involvement with her and the children seemed an invaluable support.

The next assault occurred about 4 months after their wedding. Nicole had been in a car accident in which she was thrown into the windshield, and she was hospitalized for head and facial injuries. Gary became jealous of the male doctors and angry about the length of her hospital stay. The tension was exacerbated because Nicole did not have adequate health insurance and bills were mounting quickly. After Nicole returned home, Gary was still upset and on edge. This assault was triggered when Nicole had her mother drive her to a doctor's appointment while Gary was at work. Gary returned home early that day and found that Nicole was not at home. When Nicole and her mother returned, he was waiting. He demanded to know where she had been and refused to believe her story of going to the doctor. He ripped the bandages from her forehead and chin and accused her of spending his money on plastic surgery so that she could look beautiful for other men. Gary dragged Nicole into the bathroom and began to hit her repeatedly with the back of his hand. The assault ended when Gary realized that Nicole was bleeding. He became concerned and gentle, washing her injured face with his hands, applying ice, reassuring her that everything would be alright.

Nicole went to her mother's with the children the next day. However, she was unable to come up with enough money for a deposit and first month's rent on an apartment and was frightened about her medical bills. Gary confessed that he had been taking amphetamines and made an appointment at the mental health center for counseling. He told Nicole that his first wife had left him for another man and attributed his irrational fears to his past bad experiences. Nicole and the children returned home, although against Nicole's better judgment. She was withdrawn and depressed for several months, and Gary attributed the next assault to her refusal to "forgive" him and meet his sexual needs.

Arguments in the relationship usually started over the children or over sex. As the marriage went on, Gary assumed a father role with the children, 
establishing rules and disciplining them harshly for infractions. He overruled Nicole on her decisions and accused her of attempting to turn the children against him. Although initially they adored him, the children began to fear Gary, and would jump up on the couch and sit very still when they heard his truck turning into the driveway at night. They called this "being good." When Gary got upset, he became very verbal, escalating from lectures to accusations. Verbal abuse quickly turned into physical violence. Nicole couldn't reason with Gary once an assault began. He would suddenly stop himself, become concerned over Nicole's injuries, and tell her how important she was to him. The next day he would be loving and contrite, and the household would be peaceful for a few weeks until his anger escalated again.

After the first year of marriage, Gary also became sexually abusive. Sexual attacks typically began late at night when Nicole had fallen asleep. These assaults were severe and often involved the use of other violence as well. Nicole nearly always sustained injuries. She began to suffer from sleep disorders and stomach cramps, and eventually developed ulcers. During these assaults, Gary would sometimes verbally fantasize about sex with his ex-wife's daughter. After his death, Nicole found out that charges had been filed against him for sexual molestation and for assault of his first wife but had been dropped when he left the relationship. Gary also had fantasies about killing his first wife. Nicole became increasingly afraid.

As Gary's violence became more severe, Nicole became desperate. She called the police for help if she could reach a phone during an assault. She also left Gary several times. However, her leaving or attempts to gain help only seemed to make things worse. Gary shifted his homicide fantasies about his ex-wife to threats against Nicole. He warned her that he could find her wherever she went, and that he would kill her if she tried to leave him or called the police again. He came after her the few times she left, and her family was so frightened by his behavior that Nicole quit turning to them for help. The police did not arrest Gary when they were called to the house, since he was always gone by the time they arrived, although they did transport her to the hospital several times when she needed treatment. Nicole felt that her love for Gary had ended, and she wanted only to find safety for herself and her children. She talked to the prosecutor about pressing charges or filing for divorce, but gave up when she found that Gary would remain free in the community during the long months it would take for legal action to be completed. His threats were so severe that Nicole was sure she would be killed if she took action.

The most severe assault occurred when Nicole attempted to talk with Gary about separation. Gary became furious and attacked her, beating her over the head with a heavy vase. A neighbor intervened and the police were called. Gary was jailed and Nicole was hospitalized. This time Nicole agreed to file charges, and after she left the hospital, found an apartment for herself and the children. She filed for divorce and obtained a restraining order. However, upon his release from jail, Gary followed the children home from 
school and quickly learned their location. Several times he intimidated her daughter into letting him into the apartment and then refused to leave when Nicole got home. Nicole attempted to have the restraining order enforced, but the police informed her it was no longer valid because the daughter had allowed him on the premises. Although Gary was not assaultive during this period, Nicole lived in constant fear.

When Gary won weekly visitation rights in the divorce settlement, Nicole took the children and left the state. It took Gary months, but he quit his job and found them. Nicole was ill and had been unable to find steady employment, and the children were falling behind in school. Gary just moved in and Nicole felt she didn't have the strength to fight back. He found work quickly and began to pay the bills, insisting that Nicole stay home and regain her strength. Assaultive incidents were infrequent now. Nicole told herself she'd build her strength up and try again.

Gary lost his job after 3 months, and the only work Nicole could find was on the swing shift. Gary's drinking increased, as did his verbal abuse. Increasingly, much of this was directed toward the children. Nicole was especially worried about her daughter Sarah, who had become withdrawn and silent, rarely leaving her room unless Gary made her come out and join the family. One night Nicole came home at midnight to find her daughter hiding in the garage. Sarah was crying and disheveled and admitted that Gary had been sexually abusing her but had threatened to kill her if she told. It was Friday night. Nicole promised her that they would be gone by Monday, before she had to be alone with Gary again. She and the children spent the weekend making what plans they could with Gary in the house.

Gary always spent Sundays playing pool at a favorite bar. As soon as he left the house Sunday, Nicole called a friend from work to come over and pick up the children. They packed as much as they could while they waited. When the friend arrived, Nicole loaded the children and their belongings in the car, insisting they get to safety immediately. She stayed behind for just a few minutes to pack legal papers and gather some things for herself. Nicole was barely back in the house when she heard Gary's pickup truck pull into the driveway. He slammed on the brakes and ran toward the door, yelling that she had better let him in. He had never come home that early on a Sunday. Nicole realized he must have been watching the house all along; maybe he had overheard their planning.

Nicole fastened the chain lock and ran toward the kitchen to call the police, but Gary was in a rage and was already forcing the door. Gary's .22 was in the hall closet. Nicole dialed 911 and then grabbed the gun and ran back toward the front window. She hoped that if Gary saw her with the gun it would hold him off until help arrived. As the chain lock gave way, Nicole backed up into the dining room, facing Gary but holding the gun toward the floor. She told him that she had called the police and that they would be there any minute, but he still came toward her, raging at her about leaving, grabbing a suitcase that was standing in the living room, and throwing it 
aside, flushed red in his anger. He kept saying, "You've had it now!"-a phrase Nicole remembered preceding the beating with the vase. Gary picked up a dining room chair, held it over his head and came toward her, and Nicole lifted the gun and fired once. Gary died at 10 o'clock that evening, and Nicole was arrested and charged with his murder.

This case illustrates some dynamics of homicide in which a woman kills a mate in self-defense on the basis of her assessment of danger from previous assaults and threats against herself or her children and the failure of repeated attempts to attain safety.

\section{Medical Issues}

Among professionals who are in a position to detect and prevent partner homicide, medical practitioners are especially pivotal. As Browne (1992) noted, the medical community-along with the criminal justice system-is the most likely to see women victims and thus constitutes a front line of identification and intervention. Failure to identify and intervene in cases of violence by intimates is costly to society, because assaults between intimates tend to be repeated over time, produce more injuries than assaults by strangers, and lead to both acute and chronic physical and mental health problems in survivors (Browne, 1992). However, medical settings often fail to identify violence by intimate partners as the source of physical injuries or secondary physical problems. Straus (1986) noted that medical settings can become more active in identifying high-risk cases and in promoting public health campaigns to reduce risk factors, and suggested that the public's trust in the medical field makes it well-positioned to be effectively involved. Case identification can occur in all types of medical health settings.

The surgeon general of the United States began a public health campaign in the 1980 s to combat family violence by making public pronouncements and supporting physician training. In 1992, the American Medical Association established that domestic violence is sufficiently prevalent to justify screening all women in medical and mental health settings. The American Medical Association, the American Nurse's Association, the American College of Emergency Physicians, the American College of Obstetricians and Gynecologists, the American Academy of Family Physicians, and other health organizations all have made responding to interpersonal violence a major priority. Screening instruments, curricula, and accreditation guidelines have been developed to improve the delivery of care to victims and sensitize practitioners to the scope and dynamics of violence between intimates (Campbell, 1998; Warshaw, \& Ganley, 1995). Public health researchers also have taken the lead in researching possible 
connections between firearm possession, homicide, and suicide (e.g., Cummings, Koeopsell, Grossman, Savarino, \& Thompson, 1997).

Even with these advances, most practitioners infrequently ask about violence unless protocols are in place. When asked about these silences, practitioners describe patients' unwillingness to disclose on this sensitive topic, their own feeling of helplessness about responding to disclosures, and a fear of opening a "Pandora's box" (Sugg \& Inui, 1992). However, research indicates that victims are most successfully identified by asking direct and specific questions (Feldhaus, Kozial-McLain, Amsbury, Norton, Lowenstein, \& Abbot, 1997) and that these questions can be successfully asked in a variety of medical settings (e.g., Warshaw \& Ganley, 1995; Ashur, 1993). Important roles exist for all levels of health-care and mental health-care providers in identifying individuals with past and current family violence histories and in offering appropriate services and referrals to patients and their families. (See Browne, 1992, pp. 3188-3189 for specific AMA guidelines and recommendations.) Special roles for social workers and nurses in medical settings have recently been described (Boes, 1998).

\section{Legal Issues}

\section{Legal and Extralegal Alternatives for Abused Spouses}

Although women's greatest risk of lethal and nonlethal assault is from their current and former partners, societal protections from partner assaults are still relatively recent. Before the mid-1970s, assaults against wives were considered only misdemeanors in most states, even if the same assault would have been classified as a felony if perpetrated against a stranger or acquaintance. Police were not empowered to arrest on misdemeanor charges, and emergency restraining orders were not available or lacked provisions for enforcement (Browne \& Williams, 1989). Only in the late 1970s were legal protections and shelters for battered women and their children established (Schechter, 1982).

By the early 1980s, shelters and legal alternatives were available in most of the 50 states, although such protections still vary widely by jurisdiction in content and implementation. Almost all states now have enhanced provisions for arrest, emergency and long-term restraining orders, crisis lines, and emergency shelters. Interestingly, the decline in partner homicide rates over the past 20 years shows some correlation with the establishment of protections for women faced with violent and assaultive mates. For example, Browne and Williams (1989) - in analyzing national homicide data for the years of 1976-1984 - noted over a $25 \%$ decline in the 
rates of women killing male partners over that time period, and found that those states having more domestic violence laws and other resources (e.g., shelters, crisis lines, support groups) for battered women had lower rates of partner homicides by all women. The presence of resources for intimate violence was related to the overall sharp decline in partner homicides. Stout (1989) conducted a state-by-state analysis of partner homicides by men for 1980-1982 and found lower rates associated with more shelter services and a greater number of domestic violence statutes (e.g., injunctions, warrantless arrests, domestic violence as separate offense). Stout (1992) also found that the number of women serving in state legislatures was related to lower rates of intimate homicide by male partners. Among state laws related to lower homicide rates by males were fair employment practices, equal pay, equality of public accommodations and housing, and civil injunction relief for victims of abuse (Stout, 1992). Dugan, Nagin, and Rosenfeld (in press) found similar results to these two studies in their analysis of partner homicides from 1976 to 1992 in the 29 largest U.S. cities. Decreased homicides were related to more hotlines and help accessing services, but the relationship with women's economic status was not strong. However, studies have not found a correlation between rates of men killing female intimates and the number of programs for men who batter (Browne \& Williams, 1989; Stout, 1989).

The availability and use of personal protection or restraining orders has grown steadily throughout the past 20 years. Most states have criminalized the violation of such orders, and many give police officers the authority to arrest without a warrant given probable cause that a violation has occurred. However, there are doubts about the effectiveness of these orders. For example, although many female stalking victims obtain such orders $(28 \%)$, the majority of the orders are violated (75\%: Harrell, Smith, \& Newmark, 1993; 69\%: Tjaden \& Thoennes, 1998). Sherman (1992) has called the system a "cruel hoax" for promising protection that cannot be delivered. He contends that restraining orders are often weakly enforced. Even when they are enforced, they do not seem to work well in chronic or severe cases (Sherman, 1992; Grau, Fagan, \& Wexler, 1984; Harrell \& Smith, 1996).

\section{Legal Sanctions as Deterrence}

Police training in family crisis intervention that occurred in the early 1970s claimed to reduce the incidence of family homicide (e.g., Bard, 1970). However, further analyses of these studies showed inconclusive results (Elliot, 1989; Liebman \& Schwartz, 1973). Deterrence of nonlethal violence through arrest at the misdemeanor level was compared with interventions 
consisting of police mediation or separation of the couple in a random trial experiment in the early 1980s (Sherman \& Berk, 1984). In this study, arrest appeared to be more effective in deterring further nonlethal aggression. Partly as a result of these findings, many police departments adopted proarrest or mandatory arrest policies. However, recent attempts to replicate the experiment in five sites indicate that arrest is generally not more effective in reducing recidivism than other police actions (Fagan \& Browne, 1994; Garner, Fagan \& Maxwell, 1995). Arrest seems to work most effectively as a deterrent with perpetrators who are married and employed (Sherman, 1992).

Most criminal justice strategies-restraining orders, arrest, prosecution, short jail sentences-are based on the assumption that an offender who has physically assaulted or threatened an intimate partner will rationally weigh the costs and benefits of any future assaultive actions. Yet for many men who kill, fear of abandonment or intense feelings of rage and desperation, as described earlier, cloud rationale decision making (Fagan, 1996). Past legal standards in the United States in themselves may have contributed to men feeling justified in taking extreme action toward female partners when the partners are separated from them or appear to be involved intimately with another. Historically, women have been viewed as the property of their husbands and under their husband's control (Schechter, 1982). Traditionally, courts were reluctant to intervene between a man and his wife or to "usurp" a man's authority over members of his household (e.g., Dobash \& Dobash, 1979; Weitzman, 1981; Fagan \& Browne, 1994). In cases of intimate homicide, there is a long legal and cultural tradition of viewing men's violence as being in "the heat of passion." For example, for many years, men - but not women - were sometimes legally excused for the killing of an unfaithful mate because it was done in the "heat of passion" (Coker, 1992). Today, no American jurisdiction legally allows a husband to strike his wife, and physical attacks and threats by intimate partners are taken much more seriously. However, attitudes from the past may linger about violence as being primarily "out of control" behavior.

\section{Expert Evidence at Trial}

It has only been since the late 1970s that the self-defense plea has been applied to cases in which a woman kills an intimate partner in defense of herself or a child. Prior to that, women often pleaded temporary insanity in women-perpetrated partner homicide cases (see Schneider \& Jordan, 1978; Sonkin, 1987; Thyfault, 1984; Walker, Thyfault, \& Browne, 1982 ). In general, self-defense is defined as the justifiable use of a reasonable amount of force against an adversary, when an individual reasonably believes that he or she is in 
immediate danger of being seriously hurt or killed and that the use of such force is necessary to avoid this harm. This perception-and the decision on how much force is needed to avert the danger-need only be reasonable, even if it later turns out to be wrong (e.g., LaFave \& Scott, 1972). For women faced with violence and threat in their intimate relationships, a successful application of the self-defense plea involves presenting evidence as to the reasonableness of the woman's perception that her partner could and might cause her severe harm, and her belief that she needed to take her defense into her own hands at the time the incident occurred. Having been physically assaulted or threatened by the abuser in the past is not a defense for homicide in itself; such a history is relevant only as it contributes to the woman's belief at the time of the homicide that she is in serious danger.

When women defend themselves against violent partners, the preparation of a comprehensive defense may make the difference between acquittal and long prison terms. Indeed, in the past decade, some governors have granted clemency to incarcerated battered women because they did not have the benefit of expert testimony at their trials (Gagne, 1998). Nicole was charged with first-degree murder in the shooting death of her ex-husband Gary. She went to trial pleading self-defense and used an expert witness to testify to the effects of the violence, threats, and repeated failed attempts to gain safety by fleeing or using legal resources on her perception that she was in immediate lethal danger and had to protect herself. Nicole was acquitted (although such acquittals are still rare), and she and the children returned to her family, although both she and her daughter suffered from severe depression. Guidelines now exist to help attorneys and expert witnesses prepare a case and interview the individuals involved (National Institute of Justice, 1996; Galliano \& Nichols, 1988). Expert testimony has typically centered on the concept of a battered woman syndrome or battered spouse syndrome. This testimony describes a constellation of perceptions, responses, and long-term effects of abuse that characterize many women victims of a partner's violence and help place in a larger empirical context the circumstances and facts of a particular case.

Most court rulings now allow testimony on battered woman syndrome but have restricted experts giving opinions about the "ultimate issue" of a woman's state of mind at the time of the killing. Recently, problems with the battered woman syndrome have been pointed out, including its lack of emphasis on the social causes of women's entrapment with violent mates and a lack of scientific consensus on its definition (National Institute of Justice, 1996). However, jurors still appear to need information from an expert witness on several features of self-defense homicide cases, even if they are not subsumed under a "syndrome." 
Empirical studies indicate that even contemporary jurors often are illinformed about key dynamics of violence between men and women partners (Dodge \& Greene, 1991). For example, jurors may have difficulty understanding why a battered woman might stay in a relationship that involves severe violence and abuse. Empirical evidence on the dangers of leaving a violent and threatening mate, such as that presented in the earlier part of this chapter, and the fact that separation may sharply escalate the danger faced by an abused woman, is helpful in underscoring the reasonableness of a woman's fears of retaliation if she leaves. Problems are most likely to arise if the woman does not fit the stereotype of a "good" victim. In one vignette study, if the woman was portrayed as a "bad" or dysfunctional wife or mother, she had a greater chance of being convicted, even if the levels of assault and threat she faced were held constant (Follingstad, Brondino, \& Kleinfelter, 1996).

\section{Social and Family Issues}

Many social and family issues associated with partner homicide were present in the two case descriptions. We will highlight a few of those issues here.

\section{Social Issues}

Too often, social agencies that could balance the power between the couple consider the violence a "private matter," part of a domestic squabble to which the two partners contribute equally. Fortunately, the community in which the case of Steve and Sally took place has seen some changes in the criminal justice response. The state now has a law that makes marital rape and restraining-order violations criminal offenses. There is a mandatory arrest law for spousal battery, and the local prosecutor does not usually drop complaints at the request of the victim. There is also a special detectives unit trained to deal with sexual and domestic crimes. Although these responses have not been conclusively shown to prevent homicide, there is growing evidence that a coordinated community response-e.g., law enforcement agencies, abuser programs, victim services, and health care-provides the most effective strategy for lowering rates of nonlethal violence (e.g., Murphy, Musser, \& Maton, 1998). However, it is not enough for health, mental health, police, and social service providers to be trained to identify and respond to victims of assault; public education is needed to change attitudes about male privilege and appropriate responses (Stark \& Flitcraft, 1996). 
A potential social response to partner homicide is illustrated by the events following Sally's death. This case was plea-bargained from first- to second-degree murder, and a guilty plea was entered. At Steve's sentencing hearing, a psychiatrist testified that violence was very uncharacteristic of the defendant. However, the psychiatrist used limited and biased accounts of events in the marriage because he relied primarily on Steve's story. He also stated that Steve had been pushed to the "breaking point" by Sally's "taunting." This tendency to blame women victims of crime rather than the perpetrators, especially victims who were intimately involved with their attackers, is still sometimes found in our disciplines of law and mental health.

Steve was sentenced to 10 years in prison but was released after only 3 years. While he was in prison, the children lived with his parents. Upon his release, he was awarded custody of the children. Apparently, the decision makers viewed the murder as caused by Steve's emotional distress and the victim's behavior and did not think that more prison time would act as a specific or general deterrent. They also did not seem to take into account the emotional trauma that Steve caused the children by repeatedly physically abusing and threatening their mother and then killing her. The emotional abuse suffered by children in violent marriages is now well documented (e.g., Edleson, 1999). Unfortunately, however, there is little in the way of research or policy regarding children who survive domestic homicide.

\section{Family Issues}

The homicide cases presented also illustrate some of the factors arising from the family of origin and the nuclear family. Gary's early history contained both loss and exposure to severe violence. Gary's mother died when he was only 9 years old; he idealized her and said they had been quite close. His father was extremely strict and abusive. He battered Gary's mother, his stepmother, and Gary. In spite of this, Gary admired his father and emulated him, even in his choice of a profession. Steve's harsh upbringing also was a risk marker of husband-to-wife violence (Hotaling \& Sugarman, 1986), especially of severe violence (Saunders, 1995). Sally's greater educational attainment, although not much greater than Steve's, was another risk marker (Hornung, McCullough, \& Sugimoto, 1981). Her status was likely to threaten the traditional sex-role beliefs of Steve's upbringing. Their different religious backgrounds were another such indicator (Hotaling \& Sugarman, 1986). The case of Steve and Sally also illustrates some of the relationship dynamics of wife abuse, not all of which end in murder. Despite the man's wish for a nonviolent, egalitarian mar- 
riage on a cognitive level, the structure and stresses of the marriage brought out this socially reinforced "need" for control. In both of the histories presented, the controlling behavior of the men was a repetition of what they had experienced as children. This behavior further alienated their wives, who eventually sought either temporary or permanent separation when they were not able to negotiate change in the relationship. Over time, the negative spiral accelerated, with the men seeking more control and the women seeking escape from escalating abuse and danger.

\section{Assessing Psychopathology and the Risk of Homicide}

A common reaction to descriptions of brutality by men against their female partners is to think of the perpetrator as mentally "deranged." What else would explain such severe violence or a gruesome murder by someone who professed to love the victim? However, measures of psychopathology in themselves are not very good predictors of dangerousness and usually need to be combined with environmental indicators (Monahan, 1996). Large, well-controlled studies of psychopathology with perpetrators of partner homicide have yet to be conducted. A review of prosecutor records showed that $11 \%$ of the husbands and $15 \%$ of the wives studied were reported to have had a history of mental illness, but details about the type of diagnosis were lacking (Langan \& Dawson, 1995). In one small-sample study, the profile of men who killed their wives was very similar to that of men who killed strangers, although the latter group had a greater tendency toward psychopathic traits and impulsivity (Kalichman, 1988). The psychopathic deviate scale was the most elevated in both groups. The majority (69\%) of women who killed their partners did not have significant scale elevations. In-depth case studies often report some form of dissociate reaction among perpetrators as well (Berkman, 1980; Blinder, 1984). However, standardized measures are rarely used in these studies.

If men who kill their partners are similar to men who assault without killing, then they are unlikely to suffer from severe mental disorders. In a Minnesota Multiphasic Personality Inventory (MMPI) study of men who assault female intimates, abusive men were characterized as irritable, erratic, and unpredictable. They demonstrated signs of being distrustful of others, were isolated and severely alienated, and had excessive concerns about their own masculinity (Bernard \& Bernard, 1984). Studies of nonlethal violence by men indicate that they have a range of personality disorders, but disorders related to severe violence (Saunders, 1995) may not be the same as disorders related to lethal violence. 


\section{Predicting Risk for Partner Homicide}

In an effort to predict relationships at risk for lethal violence, several lethality checklists have been developed. Some common behavioral and background characteristics have been identified among men who are killed by their female intimates. In a multivariate analysis comparing battered women who killed their partners with those who had not, Browne (1987) found seven variables that distinguished the homicide from the nonhomicide groups: (a) frequency of assault by the man, (b) severity of the woman's injuries, (c) frequency and severity of sexual assault, (d) frequency of the man's intoxication, (e) the man's drug or alcohol use, (f) the man's threats to kill the woman and others, and (g) suicide attempts or threats by the woman. Many of these same factors were found in a study by O'Keefe (1997). By the end of their relationships, women who killed their mates often were experiencing frequent and severe attacks from men who were also sexually assaulting them, drinking heavily and/or abusing other drugs, and threatening to kill them or others. The case of Nicole and Gary illustrates all of these variables to some extent. Crucial factors include the severity of the assaults and threats and the effectiveness of the woman's attempts to gain help or stop the violence. Repeated failed attempts to attain safety produce desperation in a victim and a sense of "being on one's own with the danger" when a life-threatening incident seems imminent.

Because most of the women in the studies believed they were about to be killed, the same risk factors may apply to men who kill women intimates. Campbell (1986; Stuart \& Campbell, 1989) relied on this logic when developing the initial version of her danger assessment instrument for use with battered women. It is a 15-item checklist that correlates significantly and moderately with the severity of violence and injuries reported by battered women and distinguishes among different groups of battered women as expected (e.g., emergency room setting versus community; Campbell, 1995). In addition to the factors listed by Browne (1987), Campbell asked women about the presence of guns in the home, whether their partners were violent outside the home, whether the partner controlled all aspects of the woman's life, and whether their income was below the poverty level.

Other risk assessment checklists and instruments are under development. The MOSAIC-20 (de Becker, 1997) emphasizes the role of woman's intuition. A recent study confirms that women's prediction of severe violence was as accurate as a list of factors from Campbell's checklist and other risk factors (Weisz, Tolman, \& Saunders, 2000). Hart (1990) provides a list of factors to consider in assessing lethality. In addition to many of the 
factors found in Campbell's danger assessment instrument, she includes depression in the offender and fantasies of homicide. Straus (1996) developed "criteria for identifying life-threatening risk (LTR) among violent men" from findings of the second National Family Violence Survey. Of the 17 factors associated with the perpetration of severe violence, those most unique to this list include physical abuse of a child, attitudes supporting wife abuse, injuring pets, property destruction, and police involvement. Again, it should be pointed out that "severe violence" and lethality may have a different set of predictors. Bixenstein (1996) relied on several of these sources in constructing a list of 45 risk factors for lethal spouse abuse, which he lists in descending order. His list is unique in two other ways: (1) it includes demographic indicators such as race, age, cohabitation; and (2) it includes 10 variables that can be assessed with standardized measures (e.g., empathic ability, antisocial traits, paranoid ideation).

Even if we know precursors of violence, it remains difficult to predict homicide because it is a rare event. ${ }^{3}$ For example, a review of records for spousal homicide in Detroit and Kansas City in the mid-1970s revealed that in nearly every case police had been called to the home at least once in the 2 years before the homicide (Breedlove, Kennish, Sandler, \& Sawtell, 1976). However, one needs to consider the large number of police calls that do not result in homicide. Sherman (1992) reports one analysis showing that the risk of homicide is less than 1 in 1,000 at homes with prior police calls, and increases only to 3 in 1,000 with nine or more calls. The early studies of police calls also are limited because they refer to calls to "residences" and do not analyze gender differences. Building accurate prediction models is difficult even among severe cases of partner violence, because even severe assaults rarely end in death. About 108,000 men and an equal number of women had a gun or knife used against them by an intimate partner in 1985 (based on a sample of predominantly nonpoor respondents), yet partner homicides represented less than $2 \%$ of this figure (Straus \& Gelles, 1990). Sherman and his associates found that none of the 110 Milwaukee cases involving guns and threats of death by intimates ended in homicide over a 22-month period (Sherman, Schmidt, Rogan, \& DeRiso, 1991). Post hoc analyses of cases in which a partner homicide has occurred, although helpful in identifying general risk factors, still do not account for why only a few cases of those with similar risk factors result in lethal violence.

${ }^{3}$ Rosen (1954) first pointed out the problem of predicting rare events. A highly accurate prediction formula may identify most of the "true positives" but may not be useful because of the exceedingly high rate of "false positives" it also selects. Thus, the science of predicting the most dangerous forms of behavior is still rudimentary and may never be very good (Monahan, 1996). 


\section{Treatment Options}

Therapists from a variety of disciplines seem unprepared to assess dangerousness in violent families. For example, most therapists did not suggest appropriate interventions in response to a written case description with many signs of danger (Harway \& Hansen, 1993). Even when told that the case had a lethal outcome, only a small percentage focused on the problems of the perpetrator; many focused primarily on the underlying dynamics of the couples.

Once a practitioner is able to detect some of the risk factors for lethality, there may be a legal or ethical obligation to warn or protect potential victims. Most state laws mandate practitioners to warn or protect victims if lethal violence is believed to be imminent. The landmark court decision establishing the duty to warn potential victims involved a woman who was killed by her boyfriend (Tarasoff $v$. Regents of U. of Calif., 1997). The court found that the boyfriend's therapists had failed to warn his victim after they had determined that he posed serious danger as a result of his psychological condition. The court stated that therapists are expected to: "(1) exercise a reasonable degree of skill, knowledge, and care ordinarily possessed and exercised by members of their profession; (2) having exercised such a reasonable degree of skill, therapists who find that a patient poses a serious danger of violence to others bear a duty to exercise reasonable care to protect the foreseeable victim of such danger" (pp. 438-439). Many court cases subsequent to Tarasoff also involved women in danger from intimate male partners. However, detection skills, lethality assessment, and possible protective action apply also to battered women who appear homicidal.

Sonkin and Ellison (1986) reviewed duty to warn court cases as they evolved and noted that courts gradually broadened the scope of practitioners' duty. Some recent rulings take the definition of potential victim beyond an identifiable victim and include the potential for physical and mental harm to family members and the general public (Koocher, 1988). These court actions have been curtailed, however, by laws in over 10 states (American Psychological Association, 1988). For example, a California law granted therapists immunity from lawsuit unless "the patient has communicated a serious threat of violence against a reasonably identifiable victim" (Sonkin \& Ellison, 1986, p. 206).

In many states, therapists must try to inform the victim and the police of a serious threat. Clinicians were at first concerned that the rulings would create a reluctance to treat dangerous patients and that patients, upon hearing of the duty to warn, would drop out of treatment. Apparently, such consequences have not occurred (McNeill, 1987). McNeill points out 
some of the benefits of the ruling that clinicians often overlook. For example, when the principle case (Tarasoff $v$. Regents of the U. of Calif., 1974) went before the court for a rehearing, the court broadened the options for psychotherapists. The duty to warn was broadened to the duty to protect, which means that detaining a client for observation becomes an option. McNeill encourages therapists to inquire about clients' violent propensities and any history of violence as an indicator of future violence. She suggests that the following indicators be considered:

- The extent to which the client appears to have a plan as distinguished from a fantasy.

- The specificity with which the client describes the plan.

- Whether the client has targeted a victim or a victim is reasonably foreseeable with knowledge in the therapist's possession.

- Whether triggering events are attached to the plan that will cause the client to activate it upon the occurrence of some conditions.

- Whether a dramatic or sudden change in the client's circumstance has occurred, such as divorce, loss of job, infidelity of spouse, romantic rejection, failure in an educational setting, humiliation caused by a known person, or death of a loved one.

- Whether any steps have been taken to execute the plan, such as purchasing a weapon or other dangerous material, buying an airplane ticket to visit the intended victim, saving money toward the objective, sending threats to the victim directly or through third parties, or performing minor acts as a prelude to an intended "grand finale."

Typically, treatment does not follow perpetrators into a prison setting once an intimate homicide has occurred. Men who abuse their partners and are incarcerated for homicide or attempted homicide are usually not ordered by courts to receive treatment for their violence. Even if they are, few states have prison-based programs (Center for Effective Public Policy, 1997). As in the case of Steve, the homicide is seen as an isolated "act of passion" that will never occur again. These men often make model prisoners; treatment referrals are more likely to be made for individuals who are aggressive while incarcerated. Some perpetrators also refuse treatment because they fear that any information they reveal will be used against them in an appeals process and will lengthen their time in prison.

Women incarcerated for killing their partners also have critical needs for intervention and support. Many suffer from posttraumatic stress disorder, panic disorder, and depression as a result of the violence they have experienced as well as the aftermath of the lethal incident. Many also lose custody of and even contact with their children as a result of the incident 
and their incarceration. A number of communities have established advocacy programs for these women (e.g., Bauschard, 1986). Support groups in prisons can be sponsored by corrections counselors, community shelters, mental health centers, or other entities. A major need of these women is to have their emotional, physical, and sexual abuse experiences validated (Grant, 1995) and to deal with the multiple losses involved in the homicide incident and its consequences. Even though their abuser is dead, women survivors may continue to fear him and to evidence posttraumatic stress disorder and other acute and chronic emotional and physical conditions. For women whose relationships with an abusive partner involved extreme levels of control, isolation, and invasions of privacy, the realities of prison life-including pat and body-cavity searches, middle-of-the-night bed checks, the potential for sexual assault, the necessity to follow all orders immediately, and the complete loss of privacy and freedom-may parallel aspects of earlier traumas.

Finally, more attention needs to be directed toward helping the children who survive these tragedies. Little is known about the suffering they endure. If studies of nonlethal violence are a guide, then there is reason for grave concern about the potential for boys in these families to become violent later in life. Two potent risk factors (as in Gary's case) are combined: being exposed to violence in childhood (Hotaling \& Sugarman, 1986) and the sudden, traumatic loss of a parent (Humphrey \& Palmer, 1982). The immediate and long-term emotional turmoil child survivors of parental homicide experience is likely to be great. In addition to the effects of the sudden traumatic loss of a parent and the effects of physical or sexual abuse they themselves may have suffered from the abuser, they may experience guilt that they did not somehow prevent the killing and may have split loyalties between their parents or surviving relatives if they hear differing accounts of who was to "blame."

\section{Summary}

In this chapter, we described the extent and trends of homicide between intimate partners, synthesized available empirical evidence on motives and risk factors, and presented two cases that illustrate some common dynamics involved when a spouse or lover takes the life of his or her partner. We stressed the differing rates, background characteristics, and motives of women and men perpetrators of partner homicide and discussed some legal, social, and treatment issues. Empirical studies across localities and types of populations indicate that there are clear differences between the motives of men and women, with women more likely to 
commit partner homicide in response to violence and threat by male intimates and men more likely to perpetrate homicide in response to jealousy or separation. Although the decrease in intimate homicide over the past quarter-century is promising and is related to legal and social resources for nonlethal aggression, this decrease has been much greater for the killing of male than of female intimates.

The ability to prevent any particular person from committing homicide may remain a difficult task, because homicide is a relatively rare event. Although clinicians are obligated to warn and protect potential victims in some circumstances, the science of risk prediction is in its infancy. The discovery of risk markers, however, can lead to prevention programs on a social and family level that will decrease all forms of partner violence, including its most extreme form, intimate homicide. Finally, it will be through the lessons taught to the children in our present generation, through example and words, that the most effective prevention will take place.

\section{References}

American Psychological Association. (1988, June). New laws limiting duty to protect (John Bales) (p. 18). APA Monitor. Arlington, VA: Author.

Ashur, M. L. (1993). Asking about domestic violence: Safe questions. Journal of the American Medical Association, 269, 2367.

Bard, M. (1970). Training police as specialists in family crisis intervention. Washington, DC: U.S. Government Printing Office.

Barnard, G. W., Vera, H., Vera, M. I., \& Newman, G. (1982). Til death do us part: A study of spouse murder. Bulletin of the American Academy of Psychiatry and the Law, 10, 271-280.

Bauschard, L. (1986). Voices set free. Battered women speak from prison. St. Louis, MO: Women's Self-Help Center.

Bennett, L. W. (1995). Substance abuse and the domestic assault of women. Social Work, 40, 760-771.

Berkman, A. S. (1980). The state of Michigan versus a battered wife. Bulletin of the Menninger Clinic, 44, 603-616.

Bernard, J. L., \& Bernard, M. L. (1984). The abusive male seeking treatment: Jekyll and Hyde. Family Relations, 33, 543-547.

Bixenstine, V. E. (1996). Spousal homicide. In H. V. Hall (Ed.), Lethal violence 2000. Kamuela, HI: Pacific Institute for the Study of Conflict and Aggression.

Blinder, M. (1984). The domestic homicide. Family Therapy, 11, 185-198.

Block, C. R., \& Christakos, A. (1995). Intimate partner homicide in Chicago over 29 years. Crime and Delinquency, 41, 496.

Boes, M. E. (1998). Battered women in the emergency room: Emerging roles for the ER social worker and clinical nurse specialist. In A. R. Roberts (Ed.), Battered women and their families: Intervention strategies and treatment programs (2nd ed., pp. 205-229). New York: Springer.

Breedlove, R. K., Kennish, J. W., Sandler, D. M., \& Sawtell, R. K. (1976). Domestic violence and 
the police: Kansas City. In Police Foundation (Ed.), Domestic violence and the police (pp. 23-33). Washington, DC: Police Foundation.

Browne, A. (1986). Assault and homicide at home: When battered women kill. In M. J. Saks \& L. Saxe (Eds.), Advances in applied social psychology (pp. 57-79). Hillsdale, NJ: Erlbaum. Browne, A. (1987). When battered women kill. New York: Free Press.

Browne, A. (1992) Violence against women: Relevance for medical practitioners. Journal of the American Medical Association, 267, 3184-3189.

Browne, A. (1997). Violence in marriage: Until death do us part? In A. P. Cardarelli (Ed.), Violence between intimate partners: Patterns, causes, and effects (pp. 48-69). Needham Heights, MA: Allyn \& Bacon.

Browne, A., \& Williams, K. R. (1989). Exploring the effect of resource availability and the likelihood of female-perpetrated homicides. Law and Society Review, 23, 75-94.

Browne, A., \& Williams, K. R. (1993). Gender, intimacy, and lethal violence: Trends from 1976 through 1987. Gender and Society, 7, 78-98.

Browne, A., Williams, K. R. \& Dutton, D. G. (1999). Homicide between intimate artners: A 20year review. In M. D. Smith \& M. A. Zahn (Eds.), Homicide: A sourcebook of social research. Thousand Oaks, CA: Sage.

Campbell, J. C. (1981). Misogyny and homicide of women. Advances in Nursing Science/ Women's Health, 3, 67-85.

Campbell, J. C. (1986). Nursing assessment for risk of homicide with battered women. Advances in Nursing Science, 8, 36-51.

Campbell, J. C. (1992). If I can't have you, no one can: Power and control in homicide of female partners. In J. Radford \& D. E. H. Russell (Eds.), Femicide: The politics of woman killing (pp. 99-113). Boston: Twayne Publishers.

Campbell, J. C. (1995). Prediction of homicide of and by battered women. In J.C. Campbell (Ed.), Assessing dangerousness: Violence by sexual offenders, batterers, and child abusers (pp. 96-113). Thousand Oaks, CA: Sage.

Campbell, J. C. (1998). Empowering survivors of abuse. Thousand Oaks, CA: Sage.

Cazenave, N., \& Straus, M. A. (1979). Race, class, network embeddedness and family violence. Journal of Comparative Family Studies, 10, 281-300.

Cazenave, N. A., \& Zahn, M. A. (1992). Women, murder, and male domination: Police reports of domestic homicide in Chicago and Philadelphia. In E. C. Viano (Ed.), Intimate violence: Interdisciplinary perspectives (pp. 83-96). Washington, DC: Hemisphere Publishing.

Center for Effective Public Policy. (1997, October). Findings from the batterers' intervention focus group: Recommendations to the Violence Against Women Grants Office Corrections Program Office. Silver Springs, MD: National Institute of Corrections.

Centerwall, B. S. (1995, June). Race, socioeconomic status, and domestic homicide. Journal of the American Medical Association, 273, 1755-1758.

Chimbos, P. D. (1978). Marital violence: A study of interspousal hom icide. San Francisco: R \& E Associates.

Coker, D. K. (1992). Heat of passion and wife killing: Men who batter/men who kill. Review of Law and Women's Studies, 2, 71-130.

Cooper, M., \& Eaves, D. (1996). Suicide following homicide in the family. Violence and Victims, 2, 99-112.

Crawford, M., \& Gartner, R. (1992). Woman killing: Intimate femicide in Ontario 1974-1990. Toronto: Woman's Directorate, Ministry of Social Services, Government of Ontario.

Cummings, P., Koeopsell, T. D., Grossman, D. C., Savarino, J., \& Thompson, R. S. (1997). Association between the purchase of a handgun and homicide or suicide. American Journal of Public Health, 87, 974-978.

Daly, M., \& Wilson, M. (1988). Homicide. New York: Aldine de Gruyter. 
Daniel, A. E., \& Harris, P. W. (1982). Female homicide offenders referred for pretrial psychiatric examination: A descriptive study. Bulletin of the Academy of Psychiatry and Law, 10, 261-269.

Danson, L., \& Soothill, K. (1996). Murder followed by suicide: A study of the reporting of murder followed by suicide in the Times, 1887-1990. Journal of Forensic Psychiatry, 7, 310-322.

Dawson, J. M., \& Langan, P. A. (1994). Murder in families. Washington, DC: U.S. Department of Justice, Office of Justice Programs.

Dawson, M., \& Gartner, R. (1998). Differences in the characteristics of intimate femicides. Homicide Studies, 2, 378-399.

de Becker, G. (1997). The gift of fear: Survival signals that protect us from violence. Toronto: Little Brown.

Dobash, R. E., \& Dobash, E. (1979). Violence against wives. New York: Free Press.

Dodge, M., \& Greene, E. (1991, Winter). Juror and expert conceptions of battered women. Violence and Victims, 6, 271-282.

Dugan, L., Nagin, D., \& Rosenfeld, R. (in press). Explaining the decline in intimate partner homicide: The effects of changing domesticity, women's status, and domestic violence resources. Homicide Studies.

Dutton, M. A., Hohnecker, L. C., Halle, P. M., Burghardt, K. J. (1994, October). Traumatic responses among battered women who kill. Journal of Traumatic Stress, 7, 549-564.

Dutton, D. G., \& Kerry, G. (1996). Modus operandi and psychological profiles of uxoricidal males. Unpublished study, Department of Psychology, University of British Columbia.

Dutton, D. G.. (1998). The abusive personality: Violence and control in intimate relationships. New York, NY: The Guilford Press.

Edleson, J. L. (1999). Children's witnessing of adult domestic violence. Journal of Interpersonal Violence, 14, 839-870.

Elliot, D. S. (1989). Criminal justice procedures in family violence crimes. In L. Ohlin \& M. Tonry (Eds.), Family violence: Crime and justice, a review of research (Vol. 11, pp. 427-480). Chicago: University of Chicago Press.

Fagan, J. (1996). The criminalization of domestic violence: Promises and limits. Washington, DC: National Institute of Justice, Office of Justice Programs, U.S. Department of Justice.

Fagan, J., \& Browne, A. (1994). Violence between spouses and intimates: Physical aggression between women and men in intimate relationships. In A. Reiss \& J. A. Roth (Eds.), Understanding and preventing violence. Vol. 3: Social Influences (pp. 115-292). Washington, DC: National Academy Press.

Feldhaus, K., Koziol-McLain, J., Amsbury, H., Norton, I., Lowenstein, S., \& Abbott, J. (1997). Accuracy of three brief screening questions for detecting partner violence in the emergency department. Journal of the American Medical Association, 277, 1357-1361.

Follingstad, D. R., Brondino, M. J., \& Kleinfelter, K. J. (1996, September). Reputation and behavior of battered women who kill their partners: Do these variables negate selfdefense? Journal of Family Violence, 11, 251-267.

Frieze, I. H., \& Browne, A. (1989). Violence in marriage. In L. Ohlin \& M. Tonry (Eds.), Family violence (pp. 163-218). Chicago: University of Chicago Press.

Gagne, P. (1998). Battered women's justice: The movement for clemency and the politics of selfdefense. New York: Twayne.

Galliano, B., \& Nichols, M. (1988). Mental health professional as expert witness: Psychosocial evaluation of battered women accused of homicide or assault. Journal of Interpersonal Violence, 3, 29-41.

Garner, J., Fagan, J., \& Maxwell, C. D. (1995). Published findings from the NIJ spouse assault replication program: A critical review. Journal of Quantitative Criminology, 8, 1-29. 
Gartner, R. (1990). The victims of homicide: A temporal and cross-national comparison. American Sociological Review, 55, 92-106.

Gillespie, C. K. (1989). Justifiable homicide: Battered women, self-defense, and the law. Columbus: Ohio State University.

Goetting, A. (1987). Homicidal wives. Journal of Family Issues, 8, 332-341.

Goetting, A. (1995). Homicide in families and other special populations. New York, NY: Springer Publishing.

Gondolf, E. W. (1995). Alcohol abuse, wifie assault, and power needs. Social ervice Review, 69, 274-284.

Grant, C. A. (1995). Women who kill: The impact of abuse. Issues in Mental Health Nursing, 16, 315-326.

Grau, J., Fagan, J., \& Wexler, S. (1984). Restraining orders for battered women: Issues of access and efficacy. Women and Politics, 4, 13-28.

Greenfeld, L. A., Rand, M. R., Craven, D., Klaus, P. A., Perkins, C. A., Ringel, C., Warchol, G., Maston, C., \& Fox, J. A. (1998, March). Violence by intimates: Analysis of data on crimes by current or former spouses, boyfriends, and girlfriends. Washington, DC: U.S. Department of Justice, Bureau of Justice Statistics.

Hamilton, G., \& Sutterfield, T. (1997). Comparative study of women who have and have not murdered their abusive partners. Women and Therapy, 20, 45-55.

Hampton, R. L. (1987). Family violence and homicide in the black community: Are they linked? In R. L. Hampton (Ed.), Violence in the black family (pp. 135-156). Lexington, MA: Lexington Books.

Hampton, R. L., Carrillo, R. \& Kim, J. (1998). Violence in communities of color. In R. Carrillo \& J. Tello (Eds.), Family violence and men of color (pp. 1-30). New York: Springer.

Harrell, A. V., \& Smith, B. E. (1996). Effects of restraining orders on domestic violence victims. In E. S. Buzawa \& C. G. Buzawa (Eds.), Do arrests and restraining orders work? (pp. 214242). Thousand Oaks, CA: Sage.

Harrell, A. V., Smith, B. E., \& Newmark, L. (1993). Court processing and the effects of restraining orders for domestic violence victims [Final report to the State Justice Institute]. Washington, DC: The Urban Institute.

Hart, B. (1990). Assessing whether batterers will kill. Pennsylvania Coalition Against Domestic Violence. http://www.mincava.umn.edu/hart/lethali.htm.

Harvey, (1986). Homicide among young black adults: Life in the subculture of exasperation. In D. F. Hawkins (Ed.), Homicide among black Americans (pp. 153-157). Lanham, MD: University Press of America.

Harway, M., \& Hansen, M. (Eds.). (1993). Therapist perceptions of family violence. Battering and family therapy: A feminist perspective (pp. 42-53). Thousand Oaks, CA: Sage.

Hawkins, D. F. (1987). Devalued lives and racial stereotypes: Ideological barriers to the prevention of family violence among blacks. In R. L. Hampton (Ed.), Violence in the black family (pp. 189-206). Lexington, MA: Lexington Books.

Holtzworth-Munroe, A., \& Stuart, G. L. (1994). Typologies of male batterers: Three subtypes and the differences among them. Psychological Bulletin, 116, 476-497.

Hornung, C. A., McCullough, B. C., \& Sugimoto, T. (1981). Status relationships in marriage: Risk factors in spouse abuse. Journal of Marriage and the Family, 43, 675-692.

Hotaling, G. T., \& Sugarman, D. B. (1986). An analysis of risk markers in husband to wife violence: The current state of knowledge. Violence and Victims, 1, 101-124.

Humphrey, J. A., \& Palmer, S. (1986). Stressful life events and criminal homicide. Omega: Journal of Death and Dying, 17, 299-308.

Jurik, N., \& Winn, R. (1990). Gender and homicide: A comparison of men and women who kill. Violence and Victims, 5, 227-242. 
Kalichman, S. C. (1988). MMPI profiles of women and men convicted of domestic homicide. Journal of Clinical Psychology, 4, 847-853.

Kellermann, A. L., \& Mercy, J. A. (1992). Men, women, and murder: Gender-specific differences in rates of fatal violence and victimization. Journal of Trauma, 33, 1-5.

Kellermann, A. L., Rivara, F. P., Rushforth, N. B., \& Banton, J. G. (1993). Gun ownership as a risk factor for homicide in the home. New England Journal of Medicine, 329, 1084-1091.

Koocher, G. P. (1988). A thumbnail guide to "duty to warn" cases. Clinical Psychologist, 41, 22-25.

LaFave, W. R., \& Scott, A. W., Jr. (1972). Handbook of criminal law. St. Paul, MN: West Publishing.

Langan, P. A., \& Dawson, J. M. (1995). Spouse murder defendants in large urban counties. Washington, DC: U.S. Department of Justice, Bureau of Justice Statistics.

Liebman, D., \& Schwartz, J. (1973). Police progress in domestic crisis intervention: A review. In J. Snibbe \& H. Snibbe (Eds.), The urban policeman in transition (pp. 421-472). Springfield, IL: Charles C. Thomas.

Maguigan, H. (1991). Battered women and self-defense: Myths and misconceptions in current reform proposals. University of Pennsylvania Law Review, 140, 379-486.

Mann, C. R. (1988). Getting even? Women who kill in domestic encounters. In S. L. Johann \& F. Osanka (Eds), Representing ... battered women who kill (pp. xxi., 393, 8-26). Springfield, IL: Charles C. Thomas.

Mann, C. R. (1992). Female murderers and their motives: A tale of two cities. In E. Viano (Ed.) Intimate violence: Interdisciplinary perspectives (pp. 73-81). New York: Hemisphere.

Marzuk, P. M., Tardiff, K., \& Hirsch, C. S. (1992). The epidemiology of murder-suicide. Journal of the American Medical Association, 267, 3179-3183.

McNeill, M. (1987). Domestic violence: The skeleton in Tarasoff's closet. In D. J. Sonkin (Ed.), Domestic violence on trial: Psychological and legal dimensions of family violence (pp. 197-217). New York: Springer.

Meloy, R. (1998). The psychology of stalking: Clinical and forensic perspectives. San Diego, CA: Academic Press.

Mercy, J. A., \& Saltzman, L. E. (1989). Fatal violence among spouses in the United States, 19761985. American Journal of Public Health, 79, 595-599.

Michigan Domestic Homicides, October 1995-September 1996 [http://comnet.org/dvp/ victims.html].

Monahan, J. (1996). Violence prediction: The past twenty and the next twenty years. Criminal Justice and Behavior, 23, 107-119.

Moracco, K. E., Runyan, C. W., Butts, J. D. (1998). Femicide in North Carolina, 1991-1993. Homicide Studies, 2, 422-446.

Morton, E., Runyan, C., Moracco, K. E., \& Butts, J. D. (1998). Partner homicide-suicide involving female homicide victims. A population based study in North Carolina, 19881992. Violence and Victims, 13, 91-106.

Murphy, C. M., Musser, P. H., \& Maton, K. I. (1998). Coordinated community intervention for domestic abusers: Intervention system involvement and criminal recidivism. Journal of Family Violence, 13, 263-284.

National Institute of Justice. (1996). The validity and use of evidence concerning battering and its effects in criminal trials: Report responding to Section 40507 of the Violence Against Women Act. Washington, DC: U.S. Department of Justice Office of Justice Programs.

O'Carroll, P. W., \& Mercy, J. A. (1986). Patterns and recent trends in black homicide. In D. F. Hawkins (Ed.), Homicide among black Americans (pp. 29-42). Lanham, MD: University Press of America.

O'Keefe, M. (1997). Incarcerated battered women: A comparison of battered women who killed their abusers and those incarcerated for other offenses. Journal of Family Violence, 12, 1-19. 
Plass, P. S., \& Straus, M. A. (1987, June). Intra-family homicide in the United States: Incidence, trends, and differences by region, race and gender. Paper presented at the Third National Family Violence Conference, University of New Hampshire, Durham.

Rasche, C. (1988, November). Domestic murder-suicide: Characteristics and comparisons to nonsuicidal mate killing. Paper presented at the 40th annual meeting of the American Society of Criminology, Chicago.

Roberts, A. R. (1996, September). Battered women who kill: A comparative study of incarcerated participants with a community sample of battered women. Journal of Family Violence, 11, 291-304.

Rosen, A. (1954). Detection of suicidal patients. Journal of Consulting Psychology, 18, 397-403.

Rosenfeld, R. (1997). Changing relationships between men and women: A note on the decline in intimate partner homicide. Homicide Studies, 1, 72-83.

Saltzman, L. (1992). Weapon involvement and injury outcomes in family and intimate assaults. Journal of the American Medical Association, 267, 3042.

Saltzman, L., Mercy, J. A., Rosenberg, M. L., Elsea, W. R., Napper, G., Sikes, R. K., \& Waxweiler, R. J. (1990). Magnitude and patterns of family and intimate assault in Atlanta, Georgia, 1984. Violence and Victims, 5, 3-18.

Saunders, D. G. (1992). A typology of men who batter: Three types derived from cluster analysis. American Journal of Orthopsychiatry, 62, 264-275.

Saunders, D. G. (1995). Prediction of wife assault. In J. C. Campbell (Ed.), Assessing dangerousness: Violence by sexual offenders, batterers, and child abusers (pp. 68-95). Newbury Park, CA: Sage.

Schecter, S. (1982). Women and male violence. Boston: South End Press.

Schneider, E. M., \& Jordan, S. B. (1978). Representation of women who defend themselves in response to physical or sexual assault. Family Law Review, 1, 118-132.

Schuller, R. A., \& Hastings, P. A. (1996). Trials of battered women who kill: The impact of alternative forms of expert witness. Law and Human Behavior, 20, 167-187.

Scott, P. D. (1974). Battered wives. British Journal of Psychiatry, 125, 433-441.

Sherman, L. W., \& Berk, R. A. (1984). The specific deterrent effect of arrest for domestic assault. American Sociological Review, 49, 261-272.

Sherman, L. W. (1992). Policing domestic violence: Experiments and dilemmas. New York: Maxwell Macmillan International.

Sherman, L. W., Schmidt, J. D., Rogan, D. P., \& DeRiso, C. (1991). Predicting domestic homicide: Prior police contact and gun threats. In M. Steinman (Ed.), Woman battering: Policy responses (pp. 73-93). Cincinnati, OH: Anderson Publishing.

Smith, P. H., Moracco, K., \& Butts, J. D. (1998). Partner homicide in context: A populationbased perspective. Homicide Studies, 2, 400-421.

Sonkin, D. J. (1987). The assessment of court-mandated male batterers. In D. J. Sonkin (Ed.), Domestic violence on trial (pp. 174-196). New York: Springer.

Sonkin, D. J., \& Ellison, J. (1986). The therapist's duty to protect victims of domestic violence: Where have we been and where are we going. Violence and Victims, 1, 205-214.

Stark, E., \& Flitcraft, A. (1996). Women at risk: Domestic violence and women's health. Thousand Oaks, CA: Sage.

Stawar, T. L. (1996). Suicidal and homicidal risk for respondents, petitioners, and family members in an injunction program for domestic violence. Psychological Reports, 79, $553-554$.

Stout, K. D. (1989, Summer). Intimate femicide: Effects of legislation and social services. Affilia, 4, 21-27.

Stout, K. D. (1992). "Intimate femicide?" An ecological analysis. Journal of Sociology and Social Welfare, 19, 29-50. 
Stout, K. D. (1993). Intimate femicide: A study of men who have killed their mates. Journal of Offender Rehabilitation, 19, 81-94.

Stout, K. D., \& Brown, P. (1995, Summer). Legal and social differences between men and women who kill intimate partners. Affilia, 10, 194-205.

Straus, M. A. (1986, June). Domestic violence and homicide antecedents. Bulletin of the New York Academy of Medicine, 62, 446-465.

Straus, M. A. (1996). Identifying offenders in criminal justice research on domestic assault. In E. Buzawa (Ed.), Do arrests and restraining orders work (pp. 14-29). Thousand Oaks, CA: Sage.

Straus, M. A., \& Gelles, R. (1990). Physical violence in American families: Risk factors adaptations to violence in 8,145 families. New Brunswick, NJ: Transaction Publishers.

Stuart, E. P., \& Campbell, J. C. (1989). Assessment of patterns of dangerousness with battered women. Issues in Mental Health Nursing, 10, 245-253.

Sugg, N. K., \& Inui, T. (1992). Primary care physicians' response to domestic violence: Opening the Pandora's box. Journal of American Medical Association, 267, 3157-3160.

Tarasoff v. Regents of the University of California. (1974). 118 Cal. Rptr. 129, 529 P 2d 553.

Thyfault, R. K. (1984). Self-defense: Battered women syndrome on trial. California Western Law Review, 20, 485-510.

Tjaden, P., \& Thoennes, N. (1998, April). Stalking in America: Findings from the national violence against women survey. Washington, DC: U.S. Department of Justice, National Institute of Justice Centers for Disease Control and Prevention.

Totman, J. (1978). The murderess: A psychological analysis of violent behavior. San Francisco: R \& E Research Associates.

Walker, L. E., Thyfault, R. K., \& Browne, A. (1982). Beyond the juror's ken: Battered women. Vermont Law Review, 7, 1-14.

Wallace, A. (1986). Homicide: The social reality. Sydney: New Wales Bureau of Crime and Statistics.

Warshaw, c. \& Ganley, A (1995). Improving the health care response to domestic violence: A resource manual for health care providers. San Francisco: Family Violence Prevention Fund.

Weisz, A. N., Tolman, R. M., \& Saunders, D. G. (2000). Assessing the risk of severe domestic violence: The importance of survivors' predictions. Journal of Interpersonal Violence, 15, 75-90.

Weitzman, L. (1981). The marriage contract: Spouses, lovers and the law. New York: Free Press.

White, E. C. (1985). Chain chain change: For black women dealing with physical and emotional abuse. Seattle, WA: Seal Press.

Wilbanks, W. (1983). The female homicide offender in Dade County, Florida. Criminal Justice Review, 8, 9-14.

Wilson, M., \& Daly, M. (1993). Spousal homicide risk and estrangement. Violence and Victims, 8, 3-17.

Wilson, M., Daly, M., \& Daniele, A. (1995). Familicide: The killing of spouse and children. Aggressive Behavior, 21, 275-291.

Wilson, M., Johnson, H., Daly, M. (1995) Lethal and nonlethal violence against wives. Canadian Journal of Crimiology: Special Issues: Focus on the Violence Against Women Survey, 37(3), 331-361.

Wolfgang, M. E. (1958). Patterns in criminal homicide. New York: Wiley.

Wolfgang, M. E. (1967). A sociological analysis of criminal homicide. In M. E. Wolfgang (Ed.), Studies in homicide. New York: Harper \& Row. 